\title{
Infection by a black spot-causing species of Uvulifer and associated opercular alterations in fishes from a high-desert stream in Wyoming
}

\author{
Michael C. Quist ${ }^{1, *}{ }^{,}$Michael R. Bower ${ }^{2}$, Wayne A. Hubert ${ }^{3}$ \\ ${ }^{1}$ Department of Natural Resource Ecology and Management, 339 Science II, Iowa State University, Ames, Iowa 50011, USA \\ ${ }^{2}$ National Park Service, PO Box 579, Death Valley, California 92328, USA \\ ${ }^{3}$ US Geological Survey, Wyoming Cooperative Fish and Wildlife Research Unit, Department 3166, 1000 East University \\ Avenue, University of Wyoming, Laramie, Wyoming 82071, USA
}

\begin{abstract}
Black spot is a common disease syndrome of freshwater fishes. This study provides information on the rank of density of the black spot agent and opercular bone alterations associated with at least one digenean, Uvulifer sp., infecting native and non-native catostomids and cyprinids of the Upper Colorado River Basin. We evaluated the density rank of pigmented metacercariae and associated alterations in the operculum of the bluehead sucker Catostomus discobolus, flannelmouth sucker C. latipinnis, white sucker C. commersoni, catostomid hybrids, roundtail chub Gila robusta, and creek chub Semotilus atromaculatus, sampled from Muddy Creek, Wyoming, USA in 2003 or 2004. All fish species contained individuals that exhibited gross signs of the black spot agent. Bluehead and flannelmouth suckers had $100 \%$ prevalence of infection. Although the other suckers and chubs contained encysted metacercariae in at least one individual, the presence of pigmented metacercariae was not apparent (i.e. based on gross observations) in many individuals. Catostomids had higher densities of metacercariae than cyprinids, as shown by frequency distributions of density ranks. Opercular holes (i.e. holes that completely penetrated the opercle and were in direct association with the pigment associated metacercariae) and pockets (depressions on the external surface of the opercle associated with metacercariae) were abundant among catostomids but rare among cyprinids.
\end{abstract}

KEY WORDS: Black spot disease · Uvulifer sp. · Opercular lesions · Colorado River · Native fish Resale or republication not permitted without written consent of the publisher

\section{INTRODUCTION}

Questions regarding the effects of parasites on fishes have stimulated a large body of research focusing on the effects of parasitism to individuals (e.g. Lemly 1980, Ryce et al. 2004), populations (e.g. Lemly \& Esch 1984, Gilbert \& Granath 2003), and assemblages (e.g. Steedman 1991). Some parasites, such as Myxobolus cerebralis, can have deleterious effects on some species but not others (e.g. Hiner \& Moffitt 2001, Blazer et al. 2004). Consequently, understanding the prevalence and potential effects of parasites on fishes may be important for explaining patterns associated with fish population dynamics and assemblage structure.

A common disease syndrome among freshwater fishes is black spot disease (Post 1987). The black spot condition can be caused by the metacercarial stage of several species in different genera of different families of digenetic trematodes (e.g. the diplostomoids Crassiphiala and Uvulifer). When an adult is unknown and a diplostomoid metacercariae lacks pseudosuckers but encysts, that digenean is referred to as Neascus (e.g. Overstreet et al. 2002). The life cycle of these trematodes is complex, involving a series of at least 3 hosts with various fishes serving as a second intermediate host in the development of the parasites. These parasites attach to the intestinal mucosa of certain piscivorous birds (e.g. kingfishers Ceryle spp., great blue heron Ardea herodias) that consume fish infected with metacercariae, with the adult worms ultimately producing eggs. Eggs are shed in the host feces and hatch, releasing miracidia. The miracidium enters an inter- 
mediate host snail and transforms into sporocysts, which in turn produce free-swimming cercariae. Infection occurs when a fish encounters cercariae that penetrate its integument and develop into encysted metacercariae, and the worm undergoes development in the fish before it will mature in the appropriate avian final host. Encysted metacercariae of some species can survive more than $4.5 \mathrm{yr}$ in a fish (Hoffman \& Putz 1965). The characteristic black spot is the result of the fish forming a capsule of connective tissue containing melanophores around the encysted metacercaria (Davis 1967, Berra \& Au 1978).

Many researchers have investigated the effects of encysted metacercariae on fishes, but results have been inconsistent. In the laboratory, heavy infections have been shown to be fatal or to reduce growth in some cases (Hunter \& Hunter 1938, Hoffman 1956, Lemly \& Esch 1984). In natural systems, results are more variable with some studies showing deleterious effects from heavy infections by black spot agents (Harrison \& Hadley 1982, Lemly \& Esch 1984), whereas others show little or no effect from the parasite (e.g. Vinikour 1977, Baker \& Bulow 1985).

During studies of the ecology of fishes in Muddy Creek, Wyoming, we observed the widespread prevalence of metacercariae, with apparent different densities per infected individual among fish species. We also noticed that some fish often had holes in their opercles that were in direct association with grossly visible encysted metacercariae. Therefore, the purpose of this research was to assess differences in ranks of density in metacercariae among fish species, examine the prevalence and magnitude of alterations to affected opercular bones, and determine if there were agerelated patterns associated with density of infection and opercular lesions.

\section{MATERIALS AND METHODS}

Muddy Creek is a high-desert stream in the Upper Colorado River Basin (UCRB) of south-central Wyoming. The headwaters of Muddy Creek are typical of other montane stream systems in the region having sparsely forested watersheds, high channel gradients, and large substrata. Fish assemblages in headwater areas are dominated by Colorado River cutthroat trout Oncorhynchus clarkii pleuriticus, but they have been largely replaced by nonnative brook trout Salvelinus fontinalis. As the stream flows from the mountains, channel gradients are reduced to a slope of less than $1 \%$ (i.e. elevation is reduced $<1 \mathrm{~m}$ over $100 \mathrm{~m}$ of stream), and substratum is dominated by sand, silt, and fine gravel. Fish assemblages are comprised of native populations of the bluehead sucker Catostomus dis- cobolus, flannelmouth sucker C. latipinnis, speckled dace Rhinichthys osculus, and roundtail chub Gila robusta and non-native populations of the white sucker C. commersoni and creek chub Semotilus atromaculatus. Muddy Creek is one of only 2 locations in Wyoming known to contain sympatric populations of bluehead sucker, flannelmouth sucker, and roundtail chub.

Bluehead, flannelmouth, and white suckers as well as their hybrids were collected from Muddy Creek during 2003 using electrofishing and seining. Roundtail and creek chubs were collected in 2004 using electrofishing. Fish were euthanized, placed on ice, and transported to the laboratory for storage and processing. The relative density rank of metacercariae associated with black spot was assessed by grossly inspecting the entire body of each fish for encysted metacercariae. Specifically, a small grid $(24.5 \mathrm{~mm} \times 24.5 \mathrm{~mm})$ was placed on the left body surface at 3 locations (approximately equally spaced) along the midline of each fish. The number of metacercariae was then counted, regardless of their depth in host tissue, and averaged to provide an overall estimate of density. Ranks of relative density, hereafter referred to as 'density', were assigned to each fish, with $0=$ absent (metacercariae absent without microscopic confirmation), 1 = rare $(<1$ metacercariae per $6 \mathrm{~cm}^{2}$ ), 2 = low density ( 1 to 5 metacercariae per $6 \mathrm{~cm}^{2}$ ), $3=$ moderate density ( 6 to 10 metacercariae per $6 \mathrm{~cm}^{2}$ ), and $4=$ high density ( $>10$ metacercariae per $6 \mathrm{~cm}^{2}$ ). Otoliths were removed from each fish and age was estimated using a stereoscope (5 to $50 \times$ magnification) with transmitted light. The left opercle was removed from each fish, cleaned of tissue, and allowed to air dry. Alteration in the opercle was examined using a stereoscope (5 to $50 \times$ magnification) with transmitted and reflected light. Two forms of alterations were observed and recorded (Fig. 1). First, we counted the number of holes that completely penetrated the opercle. Second, we counted the number of 'pockets' present on the opercle. Pockets were defined as small pits on the external surface of the opercle that did not completely penetrate the opercle. In addition, samples of infected fish were sent to The University of Southern Mississippi Gulf Coast Research Laboratory and representative metacercariae from these samples were sent to the University of North Dakota for identification of the digenetic trematode. Morphologic and genetic analyses indicated that the trematode was Uvulifer sp. (V. Tkach \& R. Overstreet unpubl. data). Perhaps more than 1 species produced metacercariae in fishes from Wyoming, but with the available material, only 1 species could be confirmed, and it appears to be a new species already under study by Tkach \& Overstreet.

The relative frequency of the 5 density ranks of metacercariae was calculated from the estimates for 

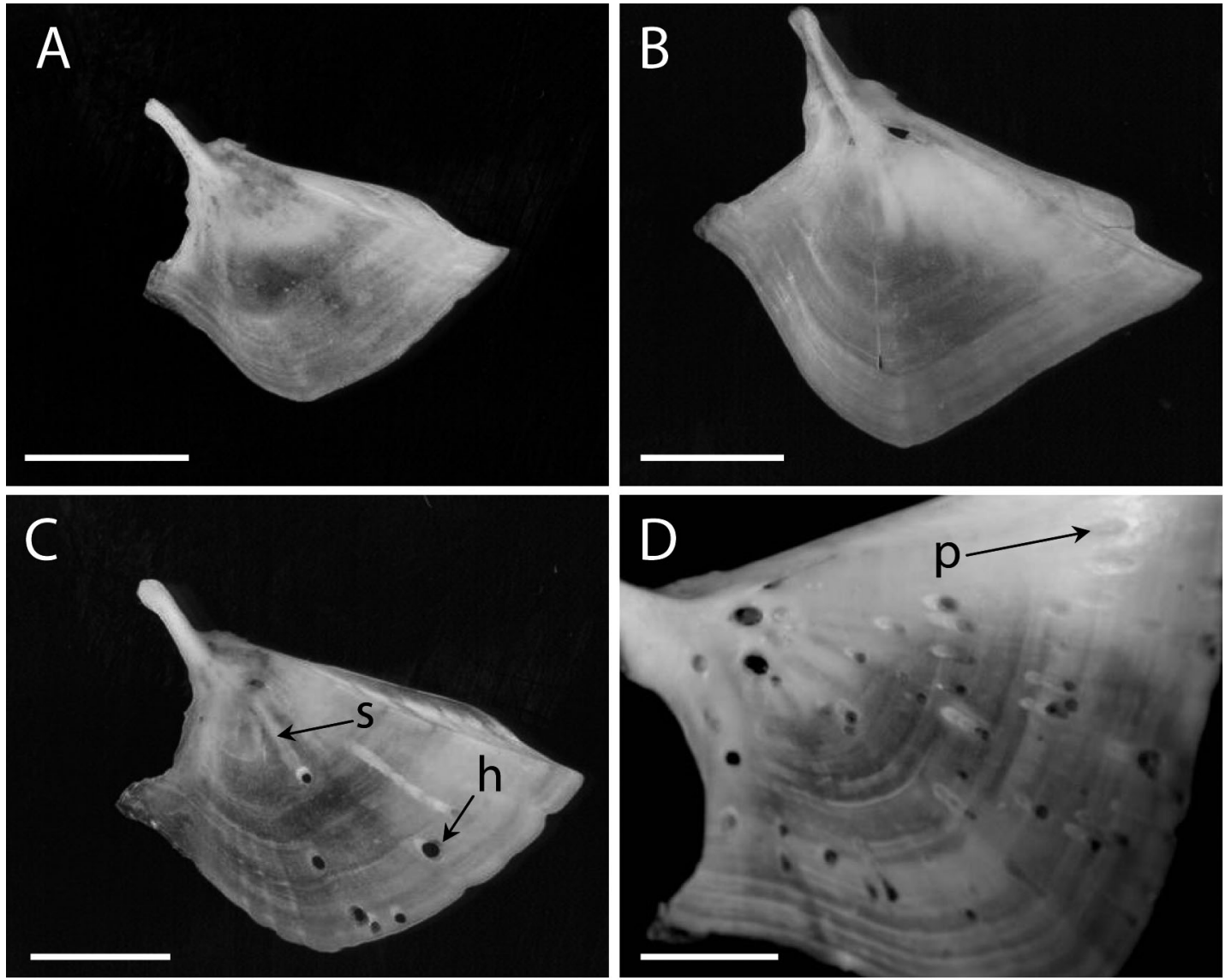

Fig. 1. Parasites infecting freshwater fishes. Operator associations with black spot-causing metacercariae in fishes from Muddy Creek, Wyoming, 2003/2004. Normal opercle from (A) bluehead sucker Catostomus discobolus (168 mm total length) or (B) flannelmouth sucker C. latipinnis $(222 \mathrm{~mm}$ ). Affected opercles from (C) bluehead sucker (203 mm) or (D) white sucker C. commersoni $(239 \mathrm{~mm})$. Scale bars $=5 \mathrm{~mm}$. Arrows: presence of holes $(\mathrm{h})$, pockets $(\mathrm{p})$, and scars $(\mathrm{s})$

each fish species. Also, we calculated the relative frequency of holes and pockets in 1 opercle of each fish. Because patterns among infections and opercular alterations in catostomid hybrids (e.g. bluehead sucker $\times$ white sucker and flannelmouth sucker $\times$ white sucker) were similar and because the exact parental origin of most of the hybrid individuals was difficult to discern, we combined catostomid hybrids for all analyses. Differences between density ranks of infection and opercular alterations among fish species were tested using a Kruskal-Wallis test (Ott 1993, Conover 1999). When the Kruskal-Wallis analysis indicated a significant difference, pair-wise comparisons were conducted using a Wilcoxon test (Conover 1999). The same analytical process was used to examine whether density ranks, number of holes, and number of pockets differed among ages for each fish species. Lastly, we investigated the relationship between rank of infection density and the number of holes and pockets using Kendall's $\tau$ correlation coefficient (Kendall 1955, Brown \& Benedetti 1977).

\section{RESULTS}

A total of 253 fish were examined for metacercariae exhibiting the black spot condition and opercle alteration (Table 1). At least 1 individual of each species showed signs of encysted metacercariae (Fig. 2). Black spot infections primarily occurred near the dermis or between fin rays and were easily observed. Encysted metacercariae did not appear to be concentrated in a particular body region and were found in nearly every external structure (i.e. for at least 1, but not all individuals) including all of the fins, the snout, head, and trunk regions, and dorsal, ventral, and lateral surfaces. Encysted metacercariae were even observed on the lips of some catostomids. Prevalence of infection was 100.0\% in bluehead ( $\mathrm{N}=27$ ind. with grossly observable encysted metacercariae) and flannelmouth suckers ( $\mathrm{N}=$ 28), $97.1 \%$ in hybrid suckers $(\mathrm{N}=65), 90.6 \%$ in white suckers $(\mathrm{N}=29)$, and $79.6 \%$ in roundtail chubs $(\mathrm{N}=39)$. Prevalence of infection was lowest for creek chubs at $24 \%(\mathrm{~N}=12)$. The bluehead sucker had the highest 
Table 1. Fishes sampled from Muddy Creek, Wyoming, 2003/2004

\begin{tabular}{|lccrcc|}
\hline Species & N & $\begin{array}{c}\text { Mean } \\
\text { length }(\mathrm{mm})\end{array}$ & SE & $\begin{array}{c}\text { Min. } \\
\text { length (mm) }\end{array}$ & $\begin{array}{c}\text { Max. } \\
\text { length (mm) }\end{array}$ \\
\hline Bluehead sucker & 27 & 209 & 4.5 & 161 & 254 \\
Creek chub & 50 & 131 & 3.9 & 70 & 175 \\
Flannelmouth sucker & 28 & 252 & 15.1 & 152 & 405 \\
Catostomid hybrids & 67 & 264 & 9.7 & 133 & 403 \\
Roundtail chub & 49 & 152 & 7.7 & 60 & 270 \\
White sucker & 32 & 256 & 6.3 & 180 & 386 \\
\hline
\end{tabular}

density of metacercariae, while roundtail and creek chubs had the lowest densities. We observed no significant trend in metacercariae density rank with age for any fish species.

Approximately $80 \%$ of the bluehead suckers had some form of worminduced opercular alteration (Fig. 2). White suckers, flannelmouth suckers, and catostomid hybrids also exhibited a high proportion, 40 to $65 \%$, of individuals with affected opercles. Less

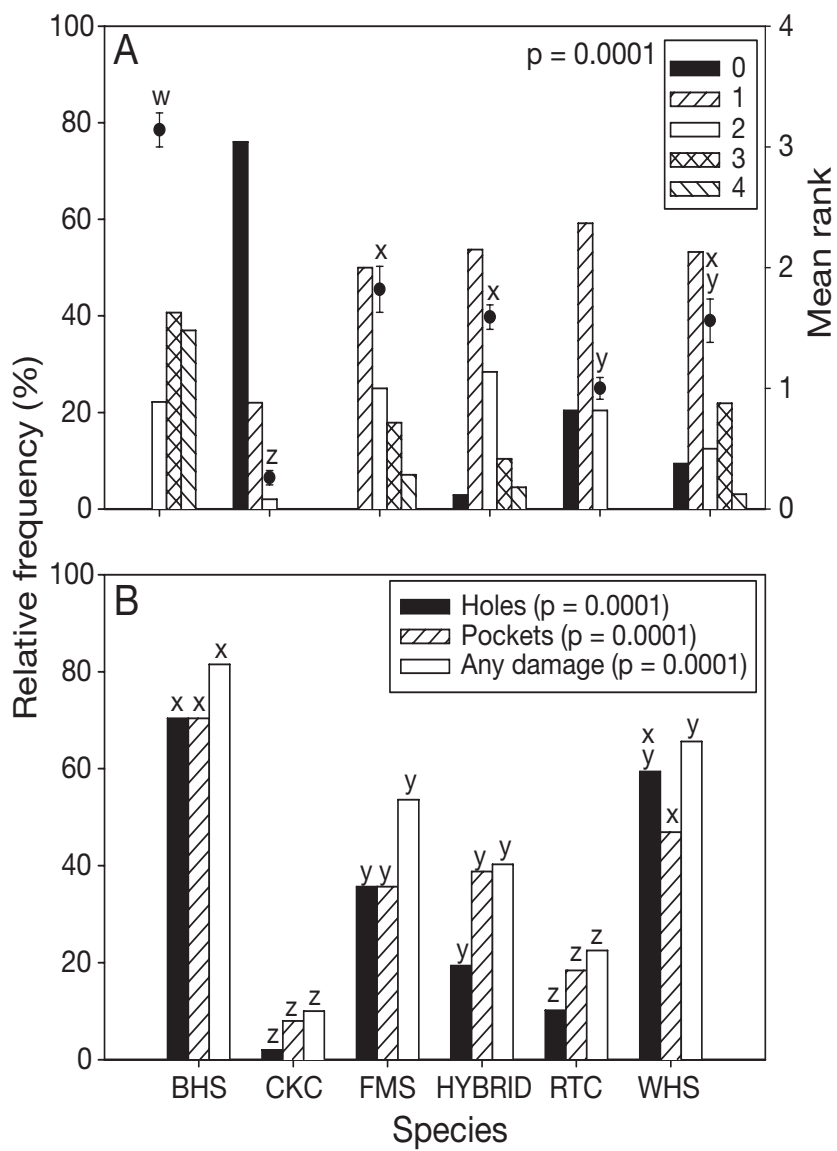

Fig. 2. Parasites infecting freshwater fishes. (A) Relative frequency of ranks of density of infection (\%) (bars) and mean rank ( ; error bars = $1 \mathrm{SE}$ ) for infections in fishes from Muddy Creek, Wyoming, 2003/2004. Metacerariae density ranks: $0=$ absent, 1 = rare, 2 = low, $3=$ moderate, $4=$ high; see 'Materials and methods' for further description. (B) Frequency of occurrence of holes, pockets, and either holes or pockets in the opercle of fishes. Fishes: bluehead sucker (BHS) Catostomus discobolus; creek chub (CKC) Semotilus atromaculatus; flannelmouth sucker (FMS) C. latipinnis; catostomid hybrids (HYBRID); roundtail chub (RTC) Gila robusta; and white sucker (WHS) C. commersoni. P-values reflect (A) whether mean density rank values differ among species or (B) whether frequency of alterations differ among fishes relative to the category of alteration. (A) Mean ranks with the same letter are not significantly different $(\mathrm{p}>0.05)$. (B) The same letter indicates the bars are not significantly different $(p>0.05)$ than $25 \%$ of the roundtail and creek chubs had altered opercles. In general, pockets in the opercle were the most prevalent form of alteration; however, the frequency of fish with holes and pockets was equal for bluehead and flannelmouth suckers, and holes were more common in opercles of the white sucker (Fig. 2). We observed no significant trend in the relationship between number of opercular holes or pockets and fish age for any fish species.

Density rank was positively related to the number of opercular holes, particularly for creek chub, flannelmouth sucker, catostomid hybrids, and white sucker (Fig. 3). Similarly, the number of pockets was positively correlated with density rank for all fishes except the bluehead sucker and roundtail chub (Fig. 4). The number of opercular holes and pockets was positively correlated for all fishes (Fig. 5).

\section{DISCUSSION}

Numerous studies have examined the prevalence and intensity of the black spot condition in fishes. Cone \& Anderson (1977) examined the seasonal prevalence of metacercariae in pumpkinseed Lepomis gibbosus in Ryan Lake, Ontario, and found that the prevalence was at or near $100 \%$ for age-1 and older fish. Other studies have described a similarly high prevalence (e.g. Evans \& Mackiewicz 1958, Lemly 1980, Lemly \& Esch 1984, Ferrara \& Cook 1998). Although prevalence of infection in one species can be high, it can be variable among species in the same system. Evans \& Mackiewicz (1958) examined the mean intensity of encysted metacercariae in 35 fish species from a New York stream and found that the intensity of metacercariae was higher in cyprinids than in members of other families, including catostomids. Steedman (1991) also found that a black spot agent was more common among cyprinids than among catostomids in Ontario streams.

Our results agree with those of Stagner (1977), who determined that catostomids had higher densities of black spot-associated metacercariae than cyprinids. 

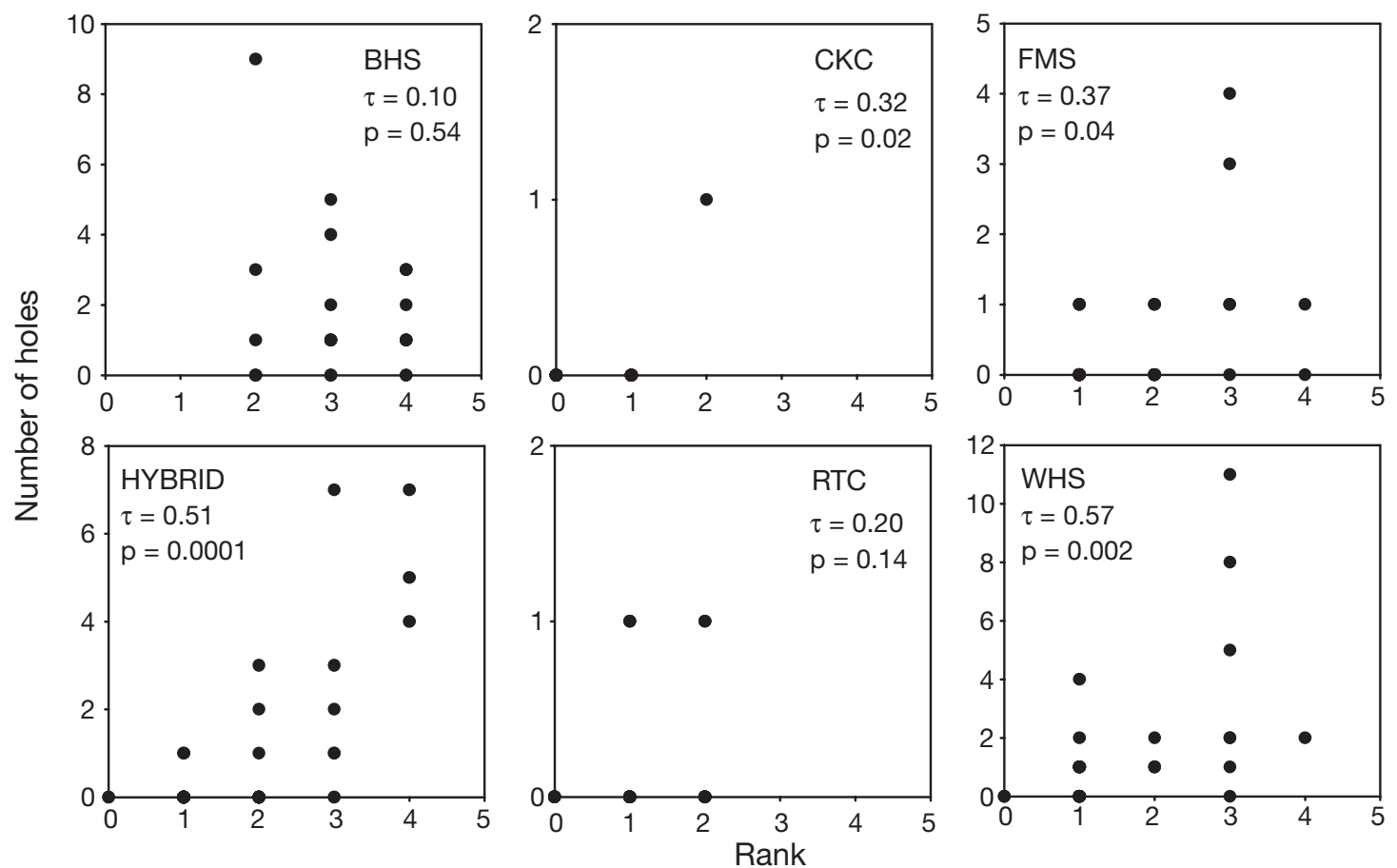

Fig. 3. Parasites infecting freshwater fishes. Relationship between rank of metacercariae density $(0=a b s e n t, 1=$ rare, $2=$ low, $3=$ moderate, $4=$ high) and the number of holes observed from an opercle from fishes in Muddy Creek, Wyoming, $2003 / 2004$. Fish abbreviations as in Fig. 2. Kendall's $\tau$ correlation coefficient and the associated p-value provide an indication of the association between variables
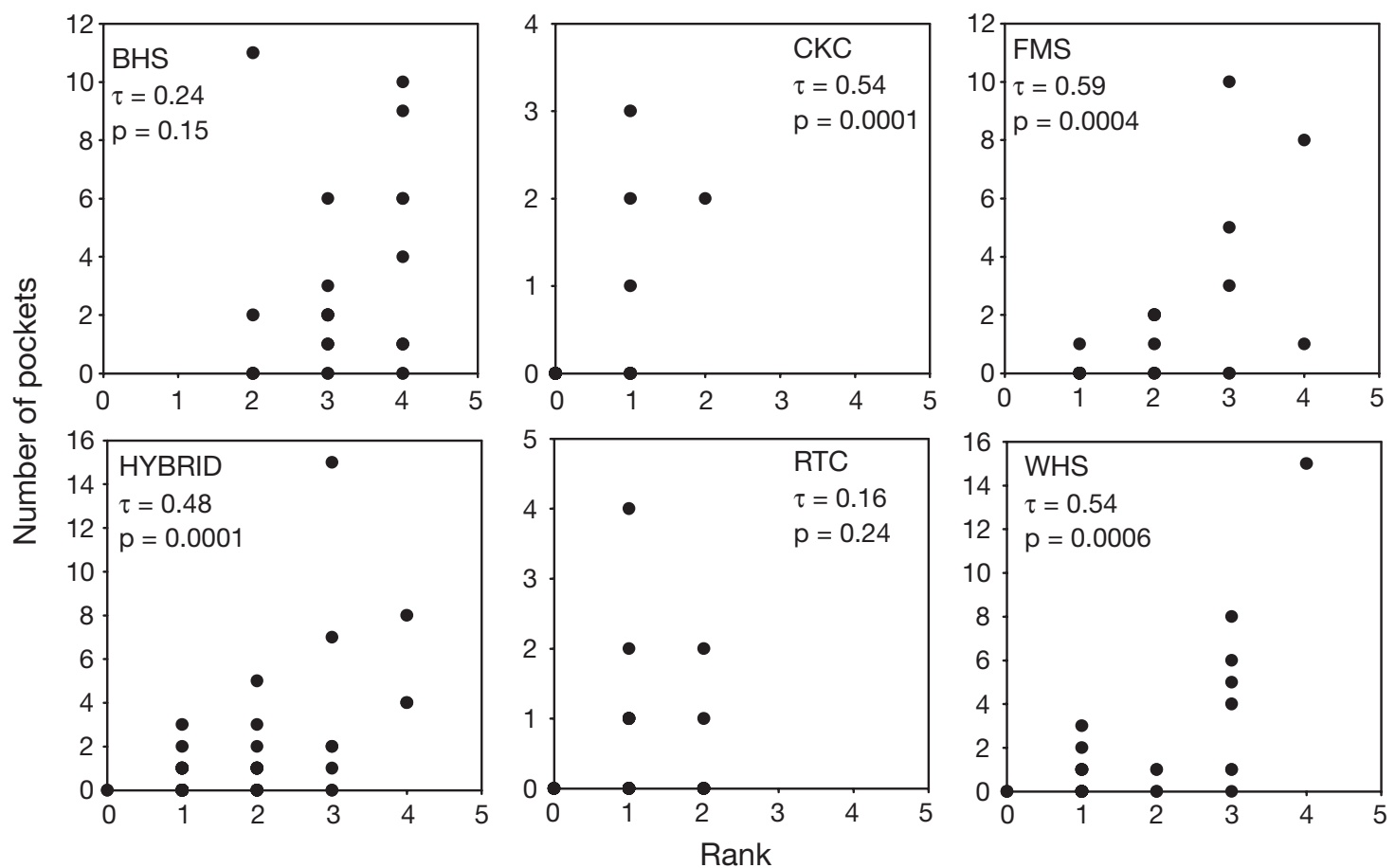

Fig. 4. Parasites infecting freshwater fishes. Relationship between metacercariae density ranks $(0=$ absent, $1=$ rare, $2=10 w$, $3=$ moderate, $4=$ high) and the number of opercular pockets from the same fish using the same statistical analysis indicated in 

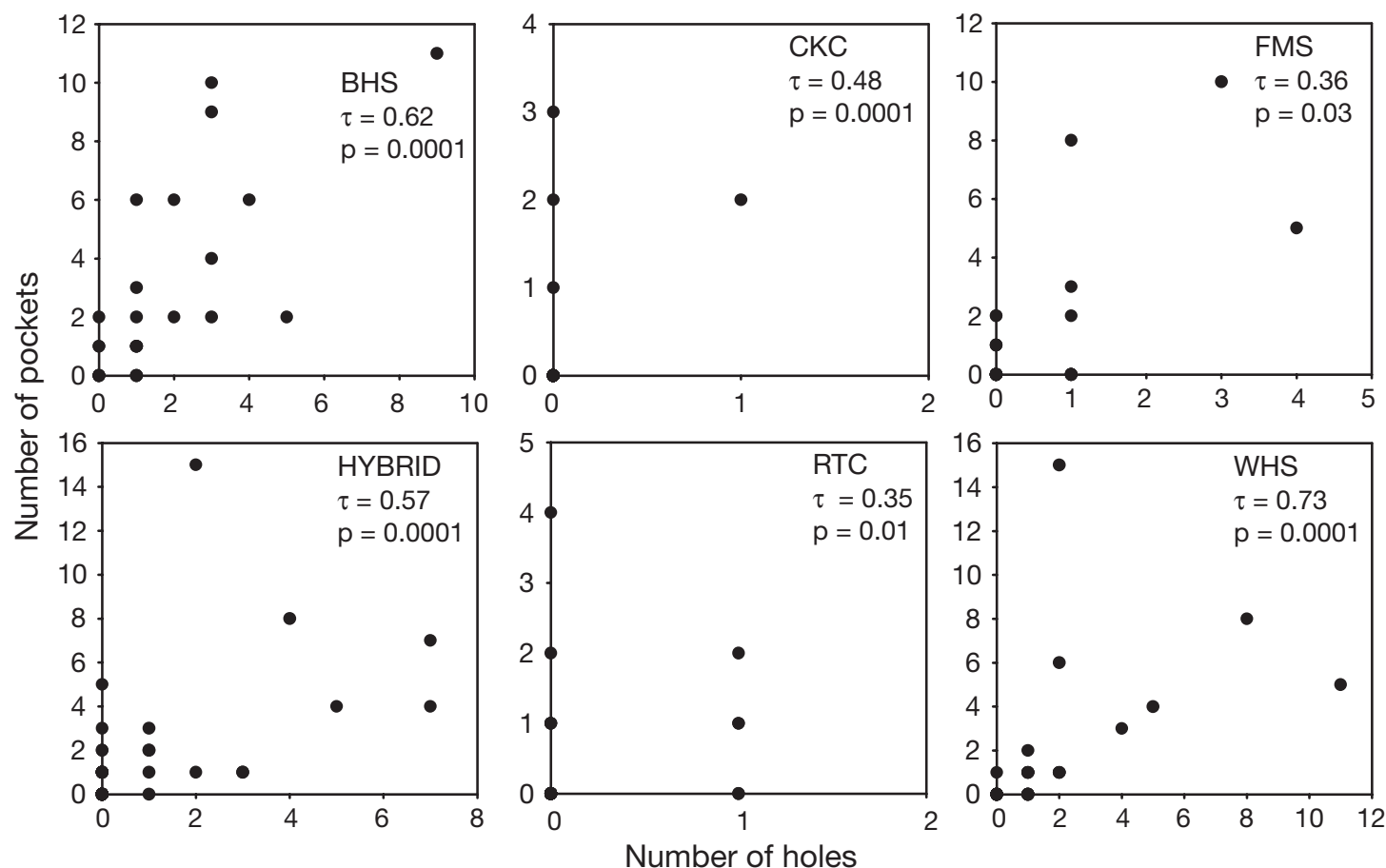

Fig. 5. Parasites infecting freshwater fishes. Relationship between the number of opercular holes and number of pockets in the same individuals reported in Figs. 3 \& 4. Fish abbreviations as in Fig. 2

The cause of this pattern in Wyoming is unclear. Evans \& Mackiewicz (1958) suggested that species inhabiting riffles had a lower prevalence and density of black spot-associated metacercariae compared with those found in pools. While this case may explain patterns in some systems, all of the fish species in Muddy Creek were found across the entire range of available habitats, including riffles and pools. Moreover, catostomids (particularly the bluehead sucker) were commonly found in riffles, but they had a high density of infection. One explanation for the observed patterns may be that the 2 cyprinid species, roundtail chub and creek chub, generally reside in the water column as opposed to the catostomid species, which are benthic (Bezzerides \& Bestgen 2002). Consequently, catostomids may be more likely to be in close association with snails and, thus, more easily infected by cercariae. Although it is unlikely that catostomids are inherently more susceptible to black spot infection than cyprinids (e.g. Evans \& Mackiewicz 1958, Steedman 1991), catostomids in Muddy Creek may be experiencing more physiologic stress due to environmental characteristics (e.g. Lemly \& Esch 1984, Steedman 1991). Moreover, different species of diplostomoids producing black spot surely have different host specificities, and all the cited references were not focusing on the same species.

Most freshwater fishes have been shown to be susceptible to black spot infections, but the pathological effects from the infection vary among species. Experimental infections of black spot-producing metacercariae have shown that high intensity of metacercariae can be fatal (e.g. Hoffman 1956, Lemly \& Esch 1984) or reduce the growth and body condition of some species (e.g. Hunter \& Hunter 1938, Lemly \& Esch 1984). Black spot condition among wild fish is usually considered relatively benign (e.g. Rabideau \& Self 1953, Vaughan \& Coble 1975, Vinikour 1977, Baker \& Bulow 1985, Hockett \& Mundahl 1989, Paradis \& Chapleau 1994). However, some studies have indicated that black spot agents can result in reduced survival, growth, and health of fishes in natural systems. For instance, Lemly \& Esch (1984) found that bluegills Lepomis macrochirus infected with Uvulifer ambloplites had reduced lipid concentrations and lower body condition relative to those without infection, resulting in higher overwintering mortality of infected fish compared with that of non-infected fish in a North Carolina pond. Harrison \& Hadley (1982) suggested that reduced growth and survival of northern pike Esox lucius in the Niagara River, New York, resulted from black spot infection.

Unlike previous studies that have focused on growth, body condition, or survival of fishes, our research suggests that black spot infection may result in physical alteration of calcified structures. We are confident that the holes observed in opercles were caused by encysted metacercariae because we observed metacercariae exhibiting melanistic encapsulations within 
the holes and we could pass a dissection needle through both the metacercaria and the opercle simultaneously. Similarly, the pockets observed in the opercles were always on the outward surface of the opercle, were roughly the same size as both the encapsulated metacercariae and holes, and both density rankings and the number of holes were concordant with the number of pockets. While some of the pockets may be the result of ongoing alterations to the opercle caused by Uvulifer sp., many could be the result of the host repairing previous injury from a metacercarial infection. For example, we observed several 'scars' on the opercles where disrupted patterns in growth rings were repeated over the life of the fish (Fig. 1C). Although we cannot determine if metacercariae and associated opercular alterations have an influence on survival, general health, or susceptibility to predation, the presence of scars suggests that some fish recover from infection.

This research shows the prevalence and density of metacercariae is high in fishes from Muddy Creek and that opercular alteration is higher among catostomids than among cyprinids. This study was conducted during a series of drought years when stressful environmental conditions (e.g. low water, high temperatures, and low dissolved oxygen) in Muddy Creek may have been detrimental for some host fishes and conducive for increased populations of planorbid rams-horn snails (first intermediate hosts) and specific bird final hosts. The effect of metacercariae on individuals, populations, and fish assemblages is currently unknown. Consequently, future research should focus on the reasons for and effects of the heavy infections.

Acknowledgements. We thank R. Beatty, R. Compton, M. Gorges, and K. Lang for assistance in the field. We also thank R. M. Overstreet, J. A. Jovonovich Alvillar, R. Palmer, and S. Curran for conducting life cycle work with chicks and rats at the University of Southern Mississippi Gulf Coast Research Laboratory (GCRL), and at the Clinical Research Laboratory, 81st Medical Support Squadron, Keesler Air Force Base, MS, with W. Brehm and C. Osiek-Comer under Protocol FKE2005009A; K. Lamey of GCRL sectioned material, and V. V. Tkach, Department of Biology, University of North Dakota, Grand Forks, ND, sequenced and identified specimens. We also thank R. Overstreet and 3 anonymous reviewers for helpful comments on an earlier version of the manuscript. Funding was provided by the US Bureau of Land Management and the US Bureau of Reclamation. The Wyoming Cooperative Fish and Wildlife Research Unit is jointly sponsored by the US Geological Survey, University of Wyoming, Wyoming Game and Fish Department, and Wildlife Management Institute.

\section{LITERATURE CITED}

Baker SC, Bulow FJ (1985) Effects of black-spot disease on the condition of stonerollers Campostoma anomalum. Am Midl Nat 114:198-199
Berra TM, Au R (1978) Incidence of black spot disease in fishes in Cedar Fork Creek, Ohio. Ohio J Sci 78:318-322

Bezzerides N, Bestgen K (2002) Status review of roundtail chub Gila robusta, flannelmouth sucker Catostomus latipinnis, and bluehead sucker Catostomus discobolus in the Colorado River basin. Colorado State University, Larval Fish Lab Contribution 118, Fort Collins, CO

Blazer VS, Densmore CL, Schill WB, Cartwright DD, Page SJ (2004) Comparative susceptibility of Atlantic salmon, lake trout and rainbow trout to Myxobolus cerebralis in controlled laboratory exposures. Dis Aquat Org 58:27-34

Brown MB, Benedetti JK (1977) Sampling behavior of tests for correlation in two-way contingency tables. J Am Stat Assoc 72:309-315

Cone DK, Anderson RC (1977) Parasites of pumpkinseed (Lepomis gibbosus L.) from Ryan Lake, Algonquin Park, Ontario. Can J Zool 55:1410-1423

Conover WJ (1999) Practical nonparametric statistics, 3rd edn. John Wiley \& Sons, New York

Davis HS (1967) Culture and diseases of game fishes. University of California Press, Berkeley, CA

Evans HE, Mackiewicz JS (1958) The incidence and location of metacercarial cysts (Trematoda: Strigeida) on 35 species of central New York fishes. J Parasitol 44:231-235

Ferrara AM, Cook SB (1998) Comparison of black-spot disease metapopulations in the central stonerollers of two warm-water streams. J Freshw Ecol 13:299-305

Gilbert MA, Granath WO Jr (2003) Whirling disease of salmonid fish: life cycle, biology, and disease. J Parasitol 89:658-667

Harrison EJ, Hadley WF (1982) Possible effects of black-spot disease on northern pike. Trans Am Fish Soc 111:106-109

Hiner M, Moffitt CM (2001) Variation in infections of Myхоbolus cerebralis in field-exposed cutthroat and rainbow trout in Idaho. J Aquat Anim Health 13:124-132

Hockett CT, Mundahl ND (1989) Effects of black spot disease on thermal tolerances and condition factors of three cyprinid fishes. J Freshw Ecol 5:67-72

Hoffman GL (1956) The life cycle of Crassiphiala bulboglossa (Trematoda: Strigeida). Development of the metacercaria and cyst, and effect on the fish hosts. J Parasitol 42:435-444

Hoffman GL, Putz RE (1965) The black-spot (Uvulifer ambloplites: Trematoda: Strigeoidea) of centrarchid fishes. Trans Am Fish Soc 94:143-151

Hunter GW III, Hunter WS (1938) Studies on host reactions to larval parasites. I. The effect on weight. J Parasitol 24:477-481

Kendall M (1955) Rank correlation methods, 2nd edn. Charles Griffin \& Company, London

Lemly AD (1980) Effects of a larval parasite on the growth and survival of young bluegill. Proc Annu Conf Southeast Assoc Fish Wildl Agencies 34:263-274

Lemly AD, Esch GW (1984) Effects of the trematode Uvulifer ambloplites on juvenile bluegill sunfish, Lepomis macrochirus: ecological implications. J Parasitol 70:475-492

Ott RL (1993) An introduction to statistical methods and data analysis, 4th edn. Duxbury Press, Belmont, CA

Overstreet RM, Curran SS, Pote LM, King DT, Blend CK, Grater WD (2002) Bolbophorus damnificus n. sp. (Digenea: Bolbophoridae) from the channel catfish Ictalurus punctatus and American white pelican Pelecanus erythrorhynchos in the USA based on life-cycle and molecular data. Syst Parasitol 52:81-96

Paradis AR, Chapleau F (1994) Impact of black spot disease upon the biology of the Phoxinus complex (Cyprinidae) of Lake Fortune, Quebec. Can J Zool 72:1611-1615 
Post GP (1987) Textbook of fish health (revised and expanded). TFH Publications, Neptune City, NJ

Rabideau TR, Self JT (1953) A study of the effects of black and yellow grubs on Lepomis cyanellus and $L$. humilis in a natural environment. Am Midl Nat 50:402-406

Ryce EKN, Zale AV, MacConnell E (2004) Effects of fish age and parasite dose on the development of whirling disease in rainbow trout. Dis Aquat Org 59:225-233

Stagner GH (1977) A study of flukes causing black spot in fishes of Wyoming. MS thesis, University of Wyoming,

Editorial responsibility: Robin Overstreet,

Ocean Springs, Mississippi, USA
Laramie, WY

Steedman RJ (1991) Occurrence and environmental correlates of black spot disease in stream fishes near Toronto, Ontario. Trans Am Fish Soc 120:494-499

Vaughan GE, Coble DW (1975) Sublethal effects of three ectoparasites on fish. J Fish Biol 7:283-294

Vinikour WS (1977) Incidence of Neascus rhinichthysi (Trematoda: Diplostomatidae) on longnose dace, Rhinichthys cataractae (Pisces: Cyprinidae), related to fish size and capture location. Trans Am Fish Soc 106:83-88

Submitted: December 19, 2005; Accepted: October 24, 2007 Proofs received from author(s): December 4, 2007 